\title{
The use of planimetric surface area in glacier mass- balance calculations: a potential source of errors
}

\author{
Frank M. Jacobsen and Wilfred H. Theakstone \\ Department of Geography, University of Manchester, Manchester M13 9PL, England
}

\begin{abstract}
Large errors in the estimation of glacier ablation and accumulation may arise from the uncritical use of planimetric surface areas in volume calculations based on specific point values. Three-dimensional digital terrain models of glacier surfaces show that the actual surface area is likely to be substantially larger than the planimetric area; with high-resolution digital terrain models, approximations of the true surface area may be as much as $20 \%$ larger. The errors are sufficient for questions to be raised about some calculations of water storage in glaciers, because incorrect surface-area values mav result in ablation being underestimated substantially. Errors may also be introduced into calculations of radiation-energy inputs to a crevassed glacier surface.
\end{abstract}

\section{INTRODUCTION}

A glacier's net mass balance generally is a small difference between large, but similar, mass fluxes: for example, 111 of the 260 seasonal (winter and summer) mass-balance values tabulated by Haakensen $(1984$, p. 55 ) are associated with a net balance which is less than $30 \%$ of those seasonal values. It follows that a general requirement of net mass-balance studies is that errors in mass-flux calculations should be minimized (Chen and Funk, 1990). The usual method of calculating ablation volumes is based on point measurements at stakes, the results of which are extrapolated to altitudinal zones. Commonly, planimetric areas are used in calculating and modelling seasonal mass-balance values (Pelto, 1988). When specific point values of ablation or accumulation are extrapolated to areas between particular contours, large errors may result, since the true surface area may be substantially larger than the planimetric area, even where the glacier is not heavily crevassed. In waterbalance calculations, such a discrepancy may result in substantial errors in the calculated proportion of the total water discharge which is thought to have been stored within the glacier (Fountain, 1992).

The surface ablation of temperate valley glaciers usually is considered to be dominated by radiation inputs, convection-induced melting and condensation (Paterson, 1981). All three mechanisms are active at the ice surface and are governed by available energy, slope and aspect; thus, melting of non-horizontal areas of ice contributes to the ablation. To rule out sloping areas as insignificant is an undue simplification, as is indicated by the large discrepancies between the planimetric surface area and the true surface area which are revealed by the use of threedimensional digital terrain models.

\section{AUSTRE OKSTINDBREEN}

The glacier Austre Okstindbreen (Fig. 1), located close to the border between Norway and Sweden, at around $66^{\circ} 01^{\prime} \mathrm{N} 14^{\circ} 07^{\prime} \mathrm{E}$, has been the subject of glaciological and related studies since 1976 by members of the Okstindan Glacier Project. In addition to annual mass-balance determination (Knudsen, 1994), the programme has included observations of surface flow of the glacier Andreasen and Knudsen, 1985), basal sliding (Andreasen, 1983), the movement of water through the glacier (Theakstone and Knudsen, 1981, 1989), drainage of a glacierdammed lake (Knudsen and Theakstone, 1988), the chemical composition of the river water issuing from the glacier (Theakstone, 1988; Theakstone and Knudsen, in press), suspended-sediment concentrations in the glacier river (Karlsen, 1991) and the chemistry of the snow cover Raben and Theakstone,

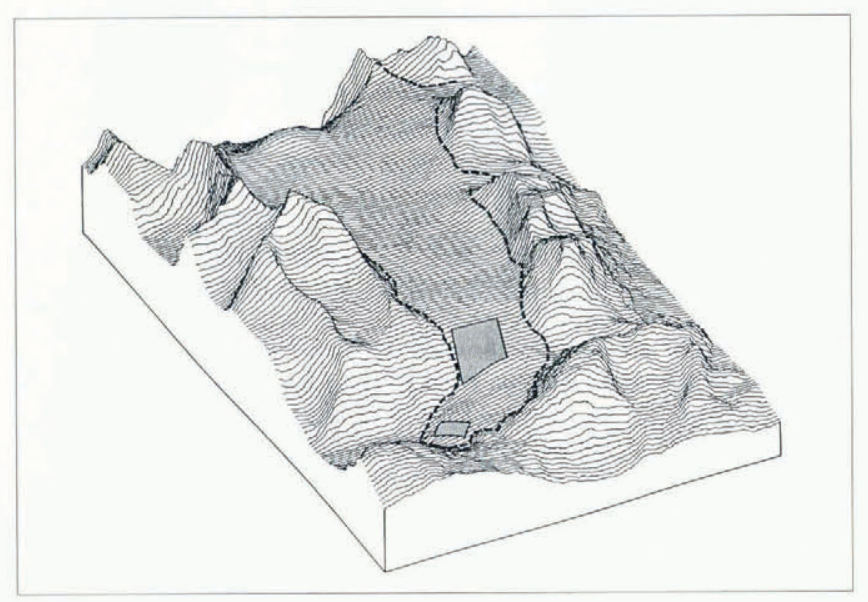

Fig. 1. Isometric parallel view of the glacier Austre Okstindbreen, showing two zones for which the planimetric and true surface areas were calculated. The orientation of the view is towards $210^{\circ}$. The vertical exaggeration is $\times 2$. The prominent mountain at the eastern side of the glacier (left centre) is Oksskolten $(1915 \mathrm{~m})$, the highest peak in northern Norway. 
1994). For many of these studies, knowledge of the area $\times$ altitude distribution is important and the use of a digital terrain model has great utility.

Austre Okstindbreen has an altitudinal range from above $1700 \mathrm{~m}$ to $730 \mathrm{~m}$. In recent years, the mean altitude of the equilibrium line has been about $1300 \mathrm{~m}$. An icefall which begins at about $1100 \mathrm{~m}$ descends through a relatively narrow channel; crevassing is particularly severe at the eastern side. Below the icefall, from about $1000 \mathrm{~m}$, the glacier surface is less broken. In the last few years, the lowest part of the glacier has become much steeper and more crevassed as the front has retreated. However, the glacier's net mass balance calculated from field observations was positive in 6 of the 7 years between 1985-86 and 1992 93 (Knudsen, 1994).

\section{DIGITAL TERRAIN MODELS}

High-precision terrestrial photogrammetric surveys covering most of the ablation zone of Austre Okstindbreen, from just above the icefall (c. $1200 \mathrm{~m}$ ) to the glacier terminus, were carried out in most summers between 1978 and 1992. Only a few small areas which were not visible from the survey stations were not included in the surveys. Maps were produced at an initial scale of $1: 5000$ with a contour interval of $10 \mathrm{~m}$. Hard-copy maps from 1981, 1985 and 1991 (Figs. 2a-c), together with an additional map of the glacier's terminal zone in 1985, plotted at a scale of $1: 2000$ with a $2 \mathrm{~m}$ contour interval (Fig. 3), were converted to digital form. The scanning process converted the maps to digital raster files, which included no directly accessible elevation data.

The files were subject to interactive automated digitizing, using the Genamap raster to vector conversion software. The strictly controlled screen digitizing and manual addition of elevation data to the digitized contour lines resulted in the production of digitized contour maps, which then were converted to triangular irregular network digital terrain models (TIN DTMs). In constructing a TIN DTM, there is no non-linear interpolation between the original data points, all of which are retained in the model. The surface which is created consists of plane irregular triangles which connect all the data points in the model (Fig. 4). The apices of each triangle are on contour lines, i.e. all three spatial coordinates are precisely defined. The true surface area of any zone is calculated by summing the areas of all the triangles within it. Both very steep slopes and complex surface features are represented accurately in a TIN model. Thus, the actual form of the surface is reproduced and the calculated surface area is very precise.

Empirical error parameters have been determined in tests with artificially created surfaces of known area. In almost all cases, the calculated surface area was slightly smaller than the true surface area, because the lower density of the data points used in the model causes artificial smoothing of the surface. The lower the density of the points, and the less accurate the model, the larger is the reduction of the calculated surface area. Thus, the true surface area is always larger than that which is calculated, even when a very accurate DTM is used and the surface roughness, represented by the ratio of the
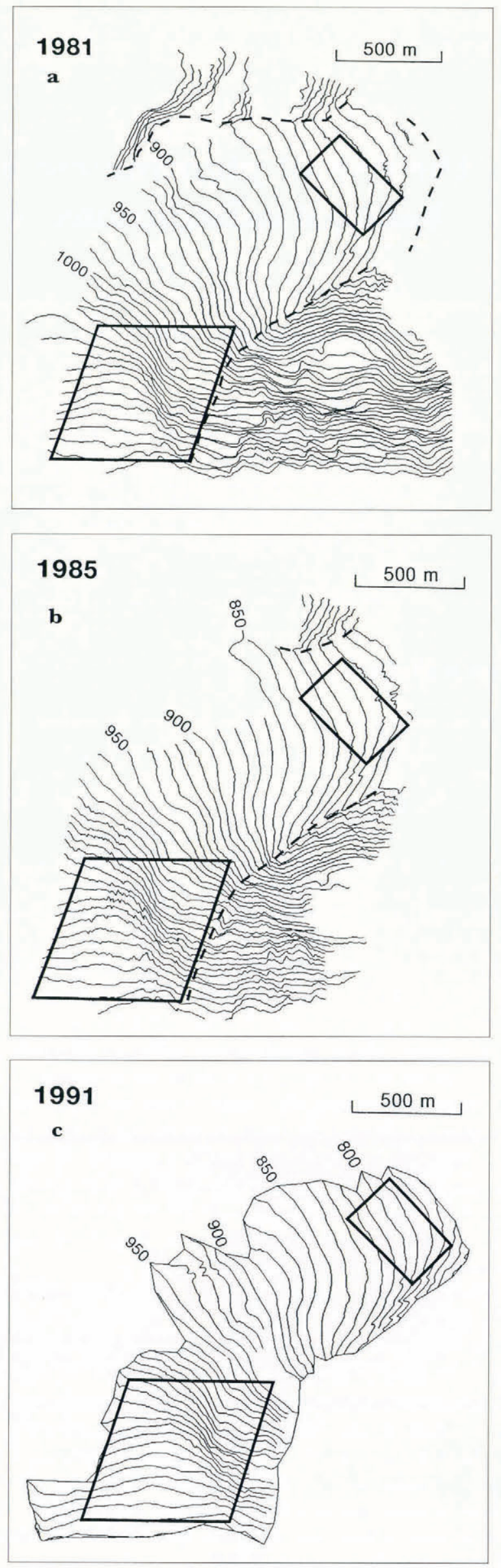

Fig. 2. Terrestrial photogrammetric map of the lower part of Austre Okstindbreen. The two zones for which the planimetric and true surface areas were calculated are indicated. a. July 1981. b. July 1985. c. July 1991. 


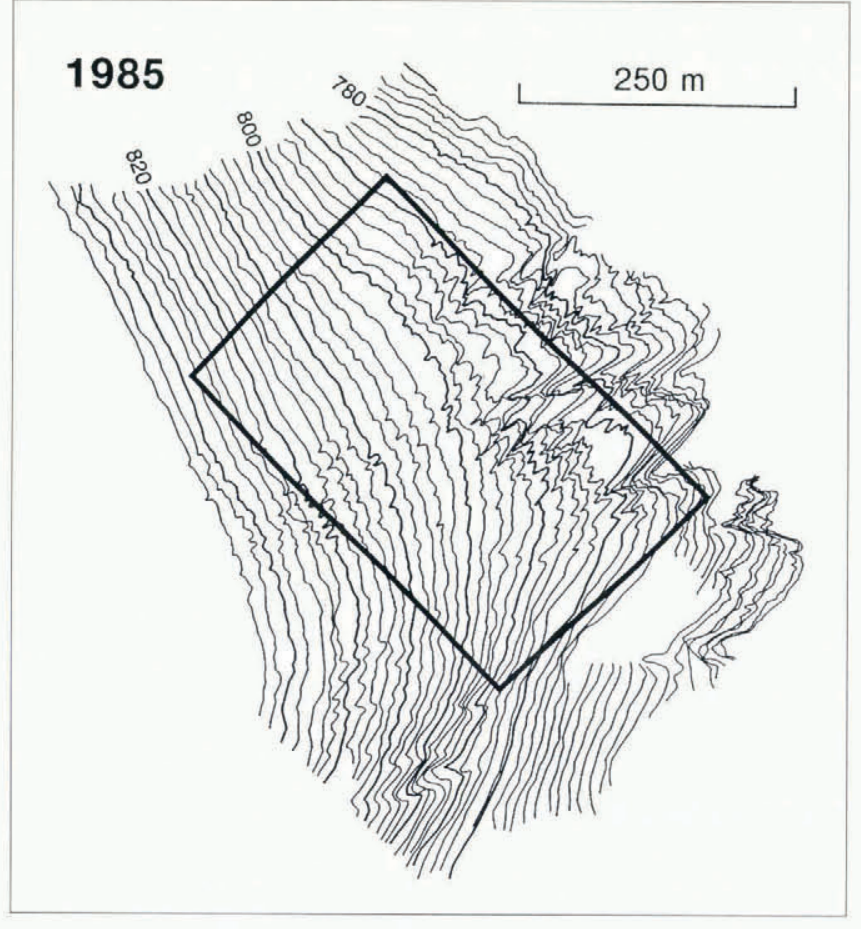

Fig. 3. Terrestrial photogrammetric map of part of Austre Okstindbreen close to the glacier front, July 1981. The contour interval is $2 \mathrm{~m}$. The crevassed nature of the lowermost part of the glacier is evident. Zone 2, for which the planimetric and true surface areas were calculated, is indicaled.

planimetric area to the "true" surface area, is lower than that actually present on a glacier.

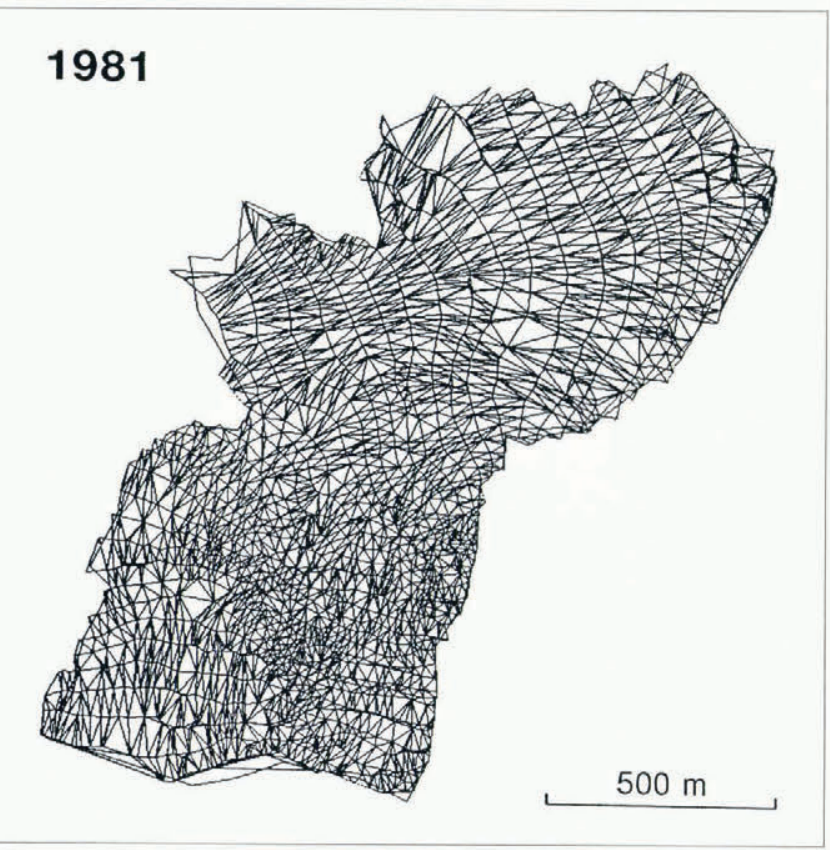

Fig. 4. The triangular irregular network ( TIN) which was the basis for the digital terrain model (DTM) of the lower part of Austre Okstindbreen in 1981. Plane irregular triangles with apices on contour lines are defined precisely in a three-dimensional coordinate system. As all the original data points are retained in the model, the actual form of the surface is reproduced and the calculated surface area is very precise.

\section{RESULTS}

For each of the four maps of Austre Okstindbreen, the planimetric and true surface areas of two zones were calculated, using the civil engineering GIS software, Genacivil. One of the zones, a parallelogram in plan view, had a planimetric area of $400000 \mathrm{~m}^{2}$; the other, bounded by a rectangular border, had a planimetric area of $100000 \mathrm{~m}^{2}$ (Fig. 2). Calculation of the planimetric area in the Genacivil program is a simple geometric operation involving no interpolation and introducing no significant errors; each triangle in the TIN model is projected on to a horizontal plane. The true surface area is calculated by summing the areas of all the triangles, without projection; there is no interpolation. Because the zones were defined by linear borders, whilst the software makes use of an automated triangle-selection process based on contours, there were small discrepancies $(<0.3 \%)$ in the planimetric areas calculated from the different maps (Table 1). Although some triangles cross the linear borders of the two zones, this introduces no error into the comparison of planimetric and true surface area, because the same triangles are used for both. The true surface area derived from the more precise 1985 map (scale 1:2000) was as much as $12 \%$ higher than that calculated with the TIN model based on the 1:5000 scale map (Table 2).

\section{DISCUSSION}

Between 1979 and 1991, as the margins of Austre Okstindbreen retreated, the planimetric area of the lower part of the glacier decreased from about $2.270 \mathrm{~km}^{2}$ to $2.033 \mathrm{~km}^{2}$, a change of $10.4 \%$. However, the change of the true surface area determined from the DTMs was from $2.445 \mathrm{~km}^{2}$ to $2.240 \mathrm{~km}^{2}$, a decrease of only $8.4 \%$. The true surface area of zone 1 on the glacier tongue decreased during the 12 year period but the calculated planimetric area increased (Table 1). Conversely, the planimetric area of the smaller, gently sloping zone 2 decreased but the true surface area increased. Crevassing was more widespread in zone 2 in 1991 than in 1979.

The data resulting from analyses of the DTMs of the lower part of Austre Okstindbreen indicate that, in calculating ablation values for mass-balance determination or in modelling glacier hydrology, the use of planimetric surface area is likely to cause errors which should neither be ignored nor dismissed as insignificant. Corrections must be made to values determined simply from planimetric area. The size of the correction which may have to be applied is indicated by the results reported here. The volume of ablation, and so the ablation-related component of discharge, may be underestimated by $5-17 \%$.

The surface roughness of most glaciers is lower at higher altitude than closer to the terminus and the discrepancy between planimetric area and true surface area is likely to decrease with increasing altitude. Thus, the discrepancies generally will be more pronounced in the ablation zone of a glacier than in the accumulation zone. However, the gently sloping, rather featureless, snow-covered surface of the accumulation zone, often without shadows or structural features, is difficult to 
Table 1. Planimetric area $(P)$ and true surface area $(S)$ for each of two zones at the surface of Austre Okstindbreen, based on four different maps

\begin{tabular}{lccccc}
\hline Tear & Scale & $\begin{array}{c}P \text {, zone } 1 \\
\mathrm{~m}^{2}\end{array}$ & $\begin{array}{c}\text { S, zone } 1 \\
\mathrm{~m}^{2}\end{array}$ & $\begin{array}{c}P, \text { zone } 2 \\
\mathrm{~m}^{2}\end{array}$ & $\begin{array}{c}\text { S, zone 2 } \\
\mathrm{m}^{2}\end{array}$ \\
\hline 1981 & $1: 5000$ & 399044.9 & 430252.1 & 100126.8 & 108768.4 \\
1991 & $1: 5000$ & 400011.2 & 426100.9 & 100016.6 & 111448.5 \\
1985 & $1: 5000$ & 400007.2 & 424161.8 & 100089.0 & 107274.9 \\
1985 & $1: 2000$ & Not used & Not used & 100011.6 & 120223.9 \\
\hline
\end{tabular}

survey with precision and is a serious handicap to photogrammetric contouring (Blachut and Müller, 1966). Elevation data there are likely to be less detailed and less accurate than those from the ablation zone, and displacement of contours may cause errors in the calculation of the area of altitudinal zones.

Table 2. Percentage difference between the planimetric and true surface areas shown in Table 1

\begin{tabular}{lccr}
\hline Year & Scale & Zone 1 & Zone 2 \\
\hline 1981 & $1: 5000$ & -7.82 & -7.95 \\
1991 & $1: 5000$ & -6.52 & -10.26 \\
1985 & $1: 5000$ & -6.03 & -6.70 \\
1985 & $1: 2000$ & Not used & -16.91 \\
\hline
\end{tabular}

The use of an accurate digital terrain model provides a much closer approximation to the true surface area of a glacier, to the areas of different altitude zones and to the area/altitude distribution than does the planimetric area calculated on the basis of a map. The more realistic distributions of surface area provided by a DTM should improve calculations of glacier mass balance, mass flux and water balance. Determining the surface areas of crevassed zones, where contours are far from smooth, is also likely to be more accurate if a DTM is used. A DTM provides opportunities for calculating area/aspect ratios and so reduces the errors introduced into calculations of radiation-energy inputs to the glacier surface. Using the true surface area of a glacier, rather than planimetric area, would be beneficial in verification procedures during modelling studies.

\section{ACKNOWLEDGEMENTS}

The authors are grateful to Professor J. T. Moller of the Geological Institute of Aarhus University, Denmark, who carried out the photogrammetric surveying at Austre Okstindbreen. The work reported here was undertaken as part of the "Glaciers and GIS" project funded by a U.K. Natural Environment Research Council grant GR3/ 8373A) to W. H. Theakstone and R. Barr.

\section{REFERENCES}

Andreasen, J. O. 1983. Basal sliding at the margin of the glacier Austre Okstindbre, Nordland, Norway. Arct. Alp. Res., 15 3), 333-338.

Andreasen, J.O. and N.T. Knudsen. 1985. Recent retreat and ice velocity at Austre Okstindbre, Norway. Z. Gletscherkd. Glazialgeol., 21, $329-340$.

Blachut, T.J. and F. Müller. 1966. Some fundamental considerations on glacier mapping. Can. J. Earth Sci., 3 6), 747-759.

Fountain, A.G. 1992. Subglacial water flow inferred from stream measurements at South Cascade Glacier, Washington, U.S.A. If Glaciol., 38 (128), 51-64.

Haakensen, N., ed. 1984. Glasiologiske undersokelser i Norge 1981. Norges Vassdrags- og Elektrisitetsvesen. Vassdragsdirektoratet. Hydrologisk Avdeling. Rapport 1-84.

Jiyang Chen and M. Funk. 1990. Mass balance of Rhonegletscher during 1982/83-1986/87. J. Glaciol., 36 123), 199-209.

Karlsen, E. 1991. Variations in grain-size distribution of suspended sediment in a glacial meltwater stream, Austre Okstindbreen, Norway. J. Glaciol, 37 (125), 113-119.

Knudsen, N. T. 1994. Mass balance, meltwater discharge and ice velocity at Austre Okstindbreen, Nordland, Norway, 1992 93. Manchester, University of Manchester, Okstindan Glacier Project Rep. 94-1.

Knudsen, N. T. and W.H. Theakstone. 1988. Drainage of the Austre Okstindbreen ice-dammed lake, Okstindan, Norway. J. Glaciol., $34(116), 87-94$.

Paterson, W.S. B. 1981. The physics of glaciers. Second edition. Oxford, etc., Pergamon Press.

Pelto, M.S. 1988. The annual balance of North Cascade glaciers, Washington, U.S.A., measured and predicted using an activity-index method. J. Glaciol., 34(117), $194-199$.

Raben, P. and W. H. Theakstone. 1994. Isotopic and ionic changes in a snow cover at different altitudes: observations at the glacier Austre Okstindbreen in 1991. Ann. Glaciol., 19, 85-91.

Theakstone, W.H. 1988. Temporal variations of isotopic composition of glacier-river water during summer: observations at Austre Okstindbreen, Okstindan, Norway. J. Glaciol., 34(118), $309-317$.

Theakstone, W.H. and N. T. Knudsen. 1981. Dye tracer tests of water movement at the glacier Austre Okstindbreen, Norway. Nor. Geogr. Tidsskr., 35 (1), 21-28.

Theakstone, W.H. and N.T. Knudsen. 1989. Temporal changes of glacier hydrological systems indicated by isotopic and related observations at Austre Okstindbreen, Okstindan, Norway, 1976 87. Ann. Glaciol., 13, 252-256.

Theakstone, W.H. and N.T. Knudsen. In press. Isotopic and ionic variations in glacier river water during three contrasting ablation seasons. Hydrological Processes. 